\title{
Techno-Economic Feasibility Study of Solar and Wind Based Irrigation Systems in Northern Colombia
}

\author{
Javier Cuellar Bolaños ${ }^{1, *}$, Willington Ortiz Orozco ${ }^{2}$ and Ramchandra Bhandari ${ }^{3}$ \\ ${ }^{1}$ Consulting Engineer, Wuppertal Institute for Climate, Environment and Energy / Döppersber 19, \\ 42103, Wuppertal, Germany \\ ${ }^{2}$ Research Fellow, Wuppertal Institute for Climate, Environment and Energy / Döppersber 19, 42103, \\ Wuppertal, Germany \\ ${ }^{3}$ Prof. Dr.-Ing. / Institute for Technology and Resources Management in the Tropics and Subtropics \\ (ITT), Cologne University of Applied Sciences / Betzdorfer Strasse 2, 50679 Cologne, Germany
}

E-Mails: javier.cuellar@ smail.fh-koeln.de; willington.ortiz@wupperinst.org ; ramchandra.bhandari@fh-koeln.de

* Author to whom correspondence should be addressed; Tel.: +49-176-88247447

Received: 3 September 2014 / Accepted: 31 October 2014 / Published: 3 November 2014

\begin{abstract}
Water pumping systems powered by solar and wind energy are a clean, decentralised and economical alternative for the irrigation of crops. The intense droughts experienced over the last few years in Northern Colombia - due to the influential El Niño phenomenon - have reactivated the need for reliable water pumping irrigation systems in the region. This study aims to assess the techno-economic feasibility of solar and wind based pumping irrigation systems, taking as a case study the municipality of Piojó in the Atlántico department. In the first stage of the study the irrigation water requirements were determined by using the software CROPWAT to assess two different crop patterns that represent existing feasible alternatives for small farmers in the region: i) a common crop pattern, which represents the current average distribution of crops for subsistence farming and ii) a fruit cash crop pattern that comprises crops for which well established markets exist in the region. Solar, wind and diesel based pumping systems were sized based on the crop water demands for 1 ha. The unit irrigation costs of the three technologies, the two crop patterns and the three irrigation methods (surface, sprinkler and drip) were calculated and compared. The economic analysis was complemented by a cost-benefit analysis spanning 20
\end{abstract}


years. Our results show that both the renewable energy based pumping systems (wind and solar) can meet the irrigation water demands of small farmers in the region. The economic analysis shows that windmills are the most cost effective solution, with solar pumping systems in second place. Diesel pumping systems are the least cost effective, even when they do not require capital investment for water storage tanks. The cost benefit analysis demonstrates that none of the irrigation systems are financially feasible for providing water in a common crop pattern. In the case of the fruit cash crop scenario the highest dividends were obtained by the wind pumping system and the lowest dividends by the diesel pumping system. The lowest payback period was obtained by the windmills (7 years) and this payback period could even be shortened to 5 years if the surplus water was used to irrigate larger areas.

Keywords: solar pumping, wind, diesel, irrigation, water pumping, cost benefit analysis, cash crops

\section{Introduction}

Water pumping systems powered by solar and wind energy are a clean, decentralised and economical alternative for the irrigation of crops. Solar, and in particular wind, pumping irrigation systems have been used for many years by farmers in developing countries. Wind power was traditionally the most used energy source for pumping. Since the early 1980s, solar pumping systems have started to be considered as alternatives to wind pumping. In regions where water is scarce and there is no access to grid electricity, these renewable energy pumps are a feasible alternative to dieselpowered pumps. Currently, half of the 2.8 billion people who suffer from water scarcity live in off-grid areas [1]. This fact illustrates the strong relationship between water and energy and highlights the need for appropriate alternatives, which could be resolved by deploying solar and wind water pumping systems in combination with irrigation techniques. In agriculture the productivity of land use can be increased by taking measures that enhance the efficient use of water and energy. Irrigation is needed in order to increase food production; farming that uses irrigation produces yields that are around 2.7 times greater than those where only rainwater is used [2]. This automatically means that the amount of energy consumed for water pumping relates directly to the depth of the water table. The use of an appropriate irrigation system can help to solve this trade-off in productivity.

Among the advantages of solar and wind water pumping systems in comparison to diesel pumps are the fact that they do not depend on fossil fuels, require less maintenance (which means the minimal use of fuel, lubricants and spare parts and a corresponding minimal need for skilled labour for maintenance), as well as their contribution to the reduction in $\mathrm{CO}_{2}$ emissions. Additionally, the International Off-Grid Renewable Energy Conference (IOREC) has underlined the unique opportunity for renewable energies to power pumping and irrigation systems in rural areas as a result of the increasing cost-competitiveness of off-grid renewable energy technologies on a life-cycle basis [3].

There is a need to promote the use of decentralised solutions in rural areas in order to diversify the energy supply options for irrigation. Currently in Colombia irrigation management is centralised by the Irrigation Districts. The last of the Irrigation Districts was constructed in the late 1970s, a time when 
massive investment in irrigation was made by international financing institutions such as the World Bank [4]. However, currently only $14 \%$ of the potential irrigation area is irrigated by Irrigation Districts and the actual \% may even be lower as the operations \& maintenance have not always been properly handled by the government entities who generally own the systems [5].

The areas of Colombia with good water resources are mostly concentrated in the Pacific and the Amazon regions. Although the National Precipitation Index is over $2500 \mathrm{~mm} / \mathrm{year}$, in parts of the Caribbean Coast and the Eastern Plains subhumid climates the rainfall only amounts to 600-1000 $\mathrm{mm}$ /year, meaning that irrigation is important for guaranteeing crop growth and development during the drought periods that can occur during the crop season [4, 6-7]. The seasonal variations in precipitation make it necessary to design systems that can ensure water supply in dry periods.

The overall aim of this study is to conduct a comparative analysis between solar, wind and diesel pumping based on an economic feasibility and cash flow analysis approach. The focus of the study is to explore the feasibility of renewable energy based irrigation systems for small-scale farming systems, which are typical in the case study area. To that end a methodology is proposed that is able to capture the technical and economic performance of the three major systems implied, i.e. the pumping, the irrigation and the crop systems. This leads to the development and analysis of 18 scenarios which combine: three pumping technologies (solar, wind and diesel), three irrigation methods (surface, sprinkler and drip) and two crop scenarios (common crop and cash crop). All the scenarios, as well as the defining parameters, are based on data from locally available technologies, practices and prices.

\section{Description of the case study}

The municipality of Piojó was selected as the case study area. Piojó was selected because it is a representative case of a rural municipality in a semi-arid region of the country, without centralised irrigation schemes, and is a municipality which is not too far from a major urban centre (i.e. a market for agricultural produce). It is located in the north west of the Atlántico department, in Northern Colombia. It is part of the Caribbean plain and borders the Caribbean Sea in the north, the Guajira Peninsula in the north east and the middle Magdalena valley in the south. The municipality has an area of $258 \mathrm{~km}^{2}$ and a population in 2011 of 5089 . The population is predominantly rural and inhabitants live in small towns and villages, which is in contrast to the national and departmental trends of urban migration. The next important reference city is Barranquilla, the capital of the Colombian Caribbean Coast, $57.8 \mathrm{~km}$ away. Piojó has a semi-arid climate that is characteristic of the seasonally dry tropical forest. Despite the drought conditions characteristic of the tropical dry climate in this region, small farmers do not practice irrigation and can usually only plant crops during short periods in the rainy season between May and November.

In Piojó $74 \%$ of the working population derives its livelihood from agriculture, but the share of Piojó agriculture in the agricultural yields of the Atlántico department is very low (with the exception of a limited number of crops, such as millet, sorghum and corn). These three crops are particularly suited to the subhumid climate conditions in Piojó. The vast majority of the crops cultivated in the municipality are produced in the traditional manner, which uses little machinery, no irrigation and inadequate fertilisation, resulting in low productivity and high production costs per hectare [8]. Farmers are obligated to sell their poor quality products at prices lower than those paid to producers from other municipalities. 
2.1 Crop patterns assumed in the study

Two crop patterns were considered in order to capture the broad range of agricultural practices that are feasible in the study area:

a) The 'common crop' pattern (CP1): this crop pattern represents the most conventionally applied agricultural practices of small farmers. It comprises the main crop species cultivated in the municipality according to statistical data from 2007-2012 [9].

b) The 'cash crop' pattern (CP2): this represents a farming system oriented towards the production of products with higher commercial value. In the case of Piojó it comprises the cultivation of fruit trees. The crop species selected are based on the main fruit cash crops that are cultivated in the Atlántico and surrounding departments [10].

The list of the crop species selected and the share that they occupy in the crop pattern in a normalised land size of 1 ha can be found on Table 1 and Table 2 .

Table 1. The area and time distribution of the 'common crop' pattern (CP1)

\begin{tabular}{|l|c|c|c|c|c|c|c|c|c|c|c|c|c|}
\hline Crop & Area (\%) & Jan & Feb & Mar & Apr & May Jun & Jul & Aug & Sep & Oct & Nov & Dec \\
\hline Manioc & 13 & & & & & & & & & & & & \\
\hline First semester & & & & & & & & & & & & & \\
\hline Sorghum & 17 & & & & & & & & & & & & \\
\hline Corn & 24 & & & & & & & & & & & & \\
\hline Millet & 17 & & & & & & & & & & & & \\
\hline Watermelon & 5 & & & & & & & & & & & & \\
\hline Common bean & 7 & & & & & & & & & & & & \\
\hline Second semester & & & & & & & & & & & & & \\
\hline Sorghum & 32 & & & & & & & & & & & \\
\hline Corn & 21 & & & & & & & & & & & & \\
\hline Millet & 7 & & & & & & & & & & & & \\
\hline Watermelon & 1 & & & & & & & & & & & & \\
\hline Common bean & 8 & & & & & & & & & & & & \\
\hline
\end{tabular}

Table 2. The crop distribution of the 'cash crop' pattern (CP2)

\begin{tabular}{|c|c|}
\hline Crop & Area (\%) \\
\hline Mango & 40 \\
\hline Avocado & 30 \\
\hline Lemon & 20 \\
\hline Guanábana & 10 \\
\hline
\end{tabular}

\section{Methods and assumptions}

\subsection{Crop water requirement}

The first step in designing and operating an irrigation system is to estimate the crop water and irrigation requirements. For this step the computer programme CROPWAT 8.0 was used. This software was developed by FAO and simulates water balance models by combining crop 
evapotranspiration, rainfall, irrigation and drainage. CROPWAT calculates irrigation requirements based on climatic and crop data. Evapotranspiration (ETo) is estimated according to the FAO PenmanMontheith method by using monthly climatic data (temperature, relative humidity, wind speed, sunshine hours and rainfall). The soil moisture status is calculated from evapotranspiration, rainfall and irrigation inputs. CROPWAT calculates the crop water requirements on a 10 -day period basis by subtracting the crop evapotranspiration under standard conditions and the effective rainfall. The required crop data for calculating evapotranspiration on a specific crop are: the crop planting dates, the length of growth stages, the crop coefficient $\left(\mathrm{K}_{\mathrm{c}}\right)$ values at the different growth stages, the allowable soil moisture depletion levels, the crop rooting depth at the different growth stages and the yield response factors.

Net irrigation water requirements (IWR) are calculated as follows [11]:

$$
\mathrm{IWR}=\mathrm{K}_{\mathrm{c}} * \mathrm{ET}_{\mathrm{o}} * \mathrm{P} * \Delta \mathrm{S}
$$

where $\mathrm{P}$ is precipitation, $\Delta \mathrm{S}$ the humidity change in soil in the previous month, $\mathrm{ET}_{0}$ is the evapotranspiration coefficient and $\mathrm{K}_{\mathrm{c}}$ is the crop coefficient. The results are given in $\mathrm{mm} / \mathrm{year}$ or its equivalent in $\mathrm{m}^{3} / \mathrm{ha} /$ year.

The data and assumptions taken for the calculation of the crop water and irrigation requirements are:

Climate data: Average monthly climate data from the nearest weather station at Barranquilla, $46 \mathrm{~km}$ east of Piojó, was obtained from the Climat 2.0 database. According to the Koppen climate classification Piojó is classified into the following two sub-regions:

- Warm semi-dry and dry: characterised by low rainfall and a high tendency to aridity

- Warm semi-arid: characterised by trade winds with a dry and a rainy season

Precipitation data: Average monthly precipitation data from the last 20 years for the station of the municipality of Piojó in the township of Hibácharos was obtained from the Institute of Hydrology, Meteorology and Environmental Studies of Colombia [12]. The average annual rainfall in the department ranges from $650 \mathrm{~mm}$ to $1400 \mathrm{~mm}$ and has two different periods: one generally rainy season from May to November with the months of August, September and October being particularly wet, a long dry season from December to April and a short dry season in July.

Crop parameters: Crop parameters were obtained for the evapotranspiration conditions of the selected crops by using the methodology and data from the FAO Manual No 56 [11], due to the fact that there is little information about the crop parameters of irrigated South American crops [4].

Soil data: The soil data for the CROPWAT soil module was also derived from the FAO Manual No 56 [11].

Irrigation scheduling: The timing options suggested in CROPWAT are useful for simulating different irrigation practices and are particularly useful for simulating the yield reduction in a nonirrigation scenario. Although CROPWAT allows for the selection of up to eight timing options only 3 timing options were considered in this study in order to obtain sufficient indications about the relevance of irrigation management practices in terms of yield reduction. The selected timing options for determining yield reductions were "at critical depletion", "at fixed interval per stage" and "without irrigation". 


\subsection{Irrigation system configuration}

An irrigation system includes the interaction of a set of components that are configured according to the specific needs of each crop pattern proposed in this study. The assumptions taken for each of these components is described below.

Well features: The static head has been assumed to be common to all scenarios. In the region the static head does not normally exceed $30 \mathrm{~m}$ and according to experts the average static head in the region is $10 \mathrm{~m}$; this value has been assumed as a fixed variable for sizing the pumping system [13]. This means that the total head of the system has been assumed to be constant and is shown in Table 3 .

Table 3. Total head assumption for all systems

\begin{tabular}{|l|c|}
\hline Static head & $10 \mathrm{~m}$ \\
\hline Dynamic head change (10\%) & $3.9 \mathrm{~m}$ \\
\hline Horizontal pipe length & $4 \mathrm{~m}$ \\
\hline Storage tank height & $4.3 \mathrm{~m}$ \\
\hline Head loss & $1.17 \mathrm{~m}$ \\
\hline Total head & $23.37 \mathrm{~m}$ \\
\hline
\end{tabular}

Storage tank: In a pumping system a water storage tank is essential. The storage tank allows for the storage of water for use at times of high demand. The storage capacity recommended for irrigation systems fed by renewable pumping systems is between 0.5 and 2 days [16]. However, after some initial calculations it became clear that a storage capacity of more than 1 day would lead to impractical volumes of water storage. The decision was, therefore, made to size the storage tank volume assuming a storage capacity of 0.5 days in the month of highest water demand.

Pressure for the irrigation system: Water pressure is needed for the sprinkler and drip irrigation methods. Sprinkler irrigation requires water pressure of between 2 and 6 bar, whereas drip irrigation requires only 1 to 2 bar [14]. In order to distribute water to the sprinkler irrigation lines a multi-stagecentrifugal booster pump powered from solar panels is included in the costs of the sprinkler irrigation system. The pressure needed for drip irrigation is assumed to be obtained from the height of the water column in the storage tank. Water is gravity-distributed at a low pressure of 1-3.5 m head through drip irrigation lines.

\subsection{Pumping systems sizing}

The solar pumping system was sized by using the programme PVSYST5, a software package for the study, sizing and data analysis of complete PV systems, including PV pumping systems. PVSYST deduces the pump electrical and array nominal power for the given water needs. The pumping system for the irrigation has been assumed to be a deep well pumping system. According to the results of the PVSYST simulation the solar pump Lorentz PS1200 C-SJ5-8 fits the technical needs of all six scenarios that use solar pumping. The technical specifications of this pump type are shown in Table 4. 
Table 4. Solar Pump technical specifications

\begin{tabular}{|l|l|}
\hline Model & PS1200 C-SJ5-8 \\
\hline MPTT converter & PS 1200 Converter \\
\hline Motor type & DC motor, brushless (with MPTT input converter) \\
\hline Min. MPP oper. Voltage & $64 \mathrm{~V}$ \\
\hline Max. MPP oper. Voltage & $108 \mathrm{~V}$ \\
\hline Max. Power & $1200 \mathrm{~W}$ \\
\hline Max. Purrent & $15 \mathrm{~A}$ \\
\hline
\end{tabular}

The windmill was sized based on the sizing approach used by the local windmill manufacturer 'Jober'. Jober has a simplified diagram that enables the selection of a windmill according to the volume-head product needs. The start point for sizing the system is to know the head and the daily water needs (volume-head product) in the design month. A design month mean wind speed is then assigned to this value. The design month is found by calculating the month with the highest reference area, which is the ratio between the hydraulic power requirements and the wind power resource. Finally the appropriate windmill reference can be chosen.

In order to size the wind pumping system wind speeds were taken from the monthly average wind measurements between 1980 and 2000 from the Wind Energy Atlas of Colombia. Regional variability of wind speed has been taken into account in order to estimate the number of hours that the windmill would produce reliable water pumping. The Wind Energy Atlas of Colombia also gives indications about this variability for different climatological stations. According to Pinilla [15] the range of the most useful wind speed is between $80 \%(3.5 \mathrm{~m} / \mathrm{s})$ and $250 \%(11.15 \mathrm{~m} / \mathrm{s})$ of the annual average wind velocity. This assumption was used for estimating the number of hours in which the windmill could achieve reliable water pumping (Table 5).

Table 5. Daily number of hours of reliable wind for water pumping

\begin{tabular}{|c|c|c|c|c|c|c|c|c|c|c|c|c|}
\hline & Jan & Feb & March & April & May & June & July & Aug & Sept & Oct & Nov & Dec \\
\hline $\begin{array}{c}\text { Hours of } \\
\text { reliable } \\
\text { wind speed }\end{array}$ & 20 & 21 & 20 & 18 & 15 & 12 & 12 & 12 & 8 & 8 & 11 & 16 \\
\hline
\end{tabular}

In order to size the diesel pumping system the World Bank nomogram for the approximate sizing of engine-driven pumps was used [16]. According to this nomogram the diesel pump can be sized based on three factors: the number of hours of operation per day, the derating factor and the hydraulic power requirements. Depending on the number of hours of operation and the hydraulic power requirements selected the appropriate diesel pump size would be between 2 and $6 \mathrm{~kW}$. The pump manufacturer Barnes offers diesel pumps in the range of between 5 and $11 \mathrm{HP}(6.7-14.74 \mathrm{~kW})$. The least powerful pump available (5 HP rated power) was chosen for the diesel system sizing calculations. This corresponds to the Barnes pumps reference HD 1.550 [17]. 


\subsection{Supply of pumped water}

The water supplied by each technology differs from the irrigation demand and therefore needs to be determined for calculating the water pumping cost of each $\mathrm{m}^{3}$. This calculation takes as its basis the pumping flow rate of each pumping system as follows:

Solar Pumping: PVSYST generates values of water pumped depending on the PV system size selected for each scenario. These results were used to denote the volume of water supplied by the PV pumping system.

Wind Pumping: The water supply was calculated based on the pumping flow rate of each windmill assumed in each scenario and the data on the daily hours of reliable wind.

Diesel Pumping: The water supply is assumed to be the same as the water demand.

\subsection{Economic analysis}

Once the appropriate solar, wind and diesel pumping systems are sized for each scenario, the next step is the economic analysis, which evaluates the profitability of the investment based on the user's perspective. This analysis enables a comparison to be made between the unit water costs of the solar, wind and diesel pumping systems. The results are expressed as unit water cost $\left(€ / \mathrm{m}^{3}\right)$ by dividing the total average annual cost (annuity) by the total annual volume of water supplied.

The investment costs are converted into an average annual capital cost called the annuity using the following formula [18]:

$$
a=P V \frac{d \times(1+d)^{n}}{(1+d)^{n}-1}
$$

where a is annuity, PV is the present value, $\mathrm{d}$ is the discount rate and $\mathrm{n}$ is the number of years. This is the amount of money to be paid every year assuming that the investment was financed through a loan and covers the repayment of the initial investment and the interest on the debts throughout the lifetime of the project [16].

Future costs that occur at different times (e.g. additional income from crops, replacements and O\&M costs) are converted into present values. Two different methods are used for calculating the costs in present values. A first method is used for calculating the value of a single future payment (replacement costs) and a second method is used for calculating the total net value of a recurring annual payment (annual fuel cost or maintenance cost).

A single future payment can be calculated as follows:

$$
\mathrm{PV}=f_{\mathrm{v}} * \mathrm{DF}
$$

Where, $f_{v}$ is a single payment in the future (future value) and DF is the discount factor for a single future payment.

The discount factor DF is calculated by considering the discount rate $\mathrm{d}$, the lifetime $\mathrm{n}$ and the relative interest rate $i_{r}$. In the case where the price of a commodity rises faster than the general inflation rate a relative interest rate has to be applied in the calculation of the DF. The formula for calculating the present value with the discount factor is shown below: 


$$
P V=f v^{*}\left[\frac{\left(1+i_{r}\right)}{(1+d)}\right]^{n}
$$

The discount rate can be deduced from the market interest rate. The market interest rate is defined by Riggs et al.[19]:

$$
i_{m}=\left(1+i_{n}\right)(1+r)-1
$$

where $i_{n}$ is the nominal interest rate and $r$ is the inflation rate. Once the market interest rate is known the discount rate can be calculated using the following formula:

$$
d=\frac{i_{m}}{1+i_{m}}
$$

A summary of the main parameters assumed for the economic analysis are shown in Table 6.

Table 6. Main cost assumptions for the economic analysis

\begin{tabular}{|c|c|}
\hline Solar panel and support structure & $€ 1.17 / \mathrm{Wp}$ \\
\hline Solar pump and controller & $€ 2108$ \\
\hline Windmill & $€ 2375$ \\
\hline Diesel pump & $€ 407$ \\
\hline PV booster pump for sprinkler irrigation & $€ 953$ \\
\hline Storage tank & $€ 2570-€ 5340$ depending on the Scenario \\
\hline Irrigation technology & $\begin{array}{c}\text { Surface: } € 198 / \mathrm{ha} \\
\text { Sprinkler: } € 1661 / \mathrm{ha} \\
\text { Drip: } € 2769 / \mathrm{ha}\end{array}$ \\
\hline
\end{tabular}

\subsection{Cost-Benefit analysis}

The methodology selected for evaluating the impact of the project is the Benefit-to-Cost ratio (B/C). This tool allows us to ascertain whether and to what degree the benefits of a particular project exceed the costs. The $\mathrm{B} / \mathrm{C}$ ratio is the ratio of discounted benefits to discounted costs at a given point in time (base year). The determining factor in $\mathrm{B} / \mathrm{C}$ analysis is whether the $\mathrm{B} / \mathrm{C}$ ratio is equal to (or greater than) one [20].

$$
\mathrm{B} / \mathrm{C}=[\mathrm{PV}(\text { All Benefits })] /[\mathrm{PV}(\text { All Costs })]
$$

Therefore, in order to pursue the analysis, the cash flow of each of the 18 scenarios was simulated. For that purpose local data about crop productivity and crop prices was obtained. Data about crop productivity was taken mainly from the National Agricultural Survey, which contains data about crop 
productivity for each of the municipalities in Colombia [10]. Data for the municipality of Piojó is available and was selected for each of the considered crops. Similarly, productivity data for irrigated crops was researched in other municipalities of the Atlántico department and in cases where this was not available it was taken from other departments in Colombia.

The crop wholesale prices were obtained from average statistical data for fruit and vegetables between June 2013 and June 2014 [21]. The prices are the yearly average prices for the market at Barranquilla. In order to calculate the revenues under rain-fed conditions, a 30\% lower quality price was assumed - this is the average price difference between the average price and the lowest price found in the price list of fruit and vegetables.

Revenues were calculated year by year taking into account the expected yields and the inflation rate. In the case of the fruit cash crop pattern, revenues were only considered from the $4^{\text {th }}$ year onwards due to the fact that fruit crops need to mature for some years before producing their first fruits.

\section{Results}

\subsection{Crop water requirements}

The gross irrigation requirements for the 3 different irrigation types (surface, sprinkler and drip), assuming the timing option "at fixed interval per stage" for every 10 days, were calculated using CROPWAT and are displayed in Fig 1 (for the common crop pattern) and in Fig 2 (for the cash crop pattern). The greatest water requirements are in the first three months of the year and the different irrigation types show quite similar results. The main difference is that the cash crop pattern creates a more regular demand for water throughout the year, while in the common crop pattern there are some periods where no irrigation water is needed.

Fig 1. Gross irrigation requirements for scenarios with the 'common crop' pattern

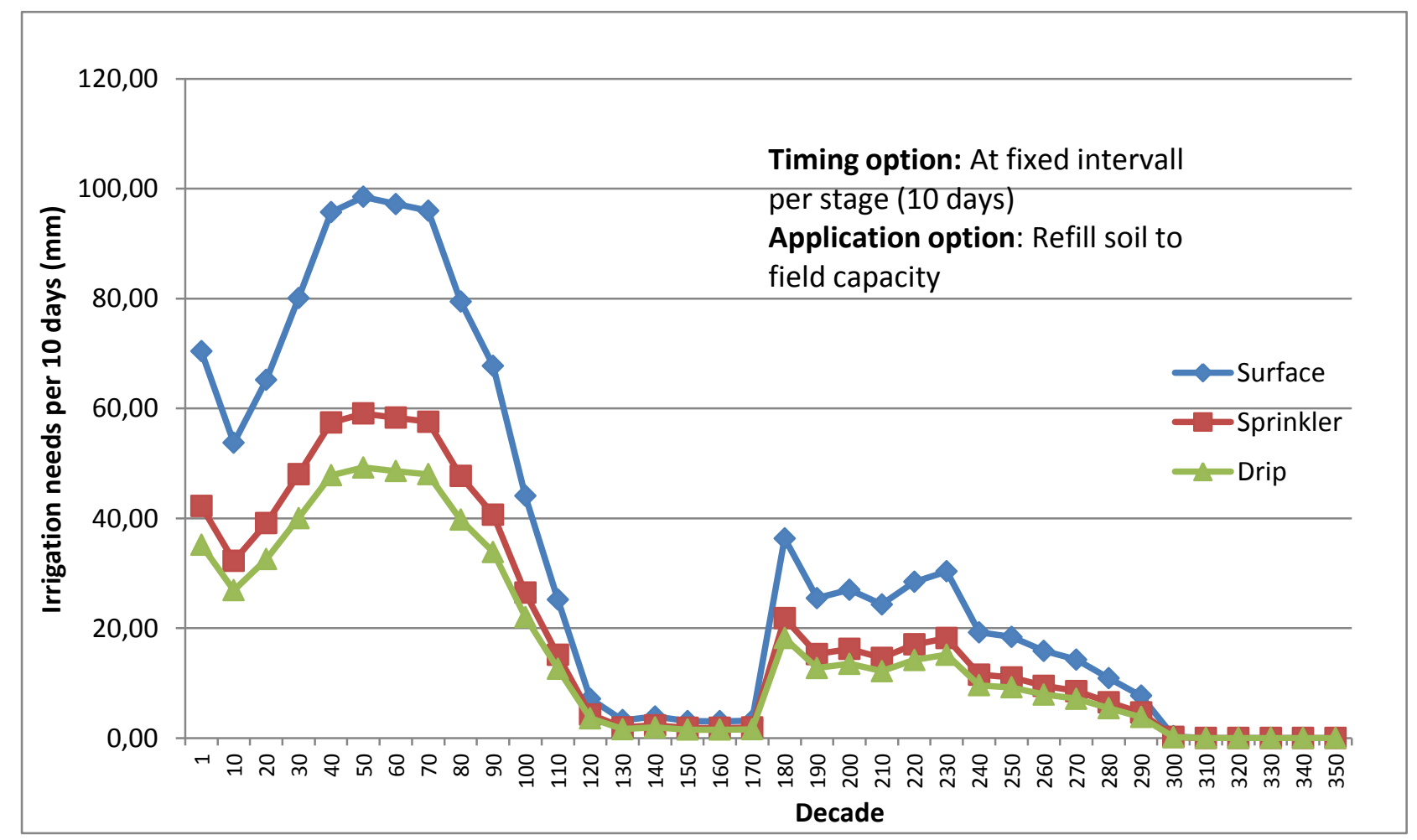


Fig 2. Gross irrigation requirements in scenarios with the 'cash crop' pattern

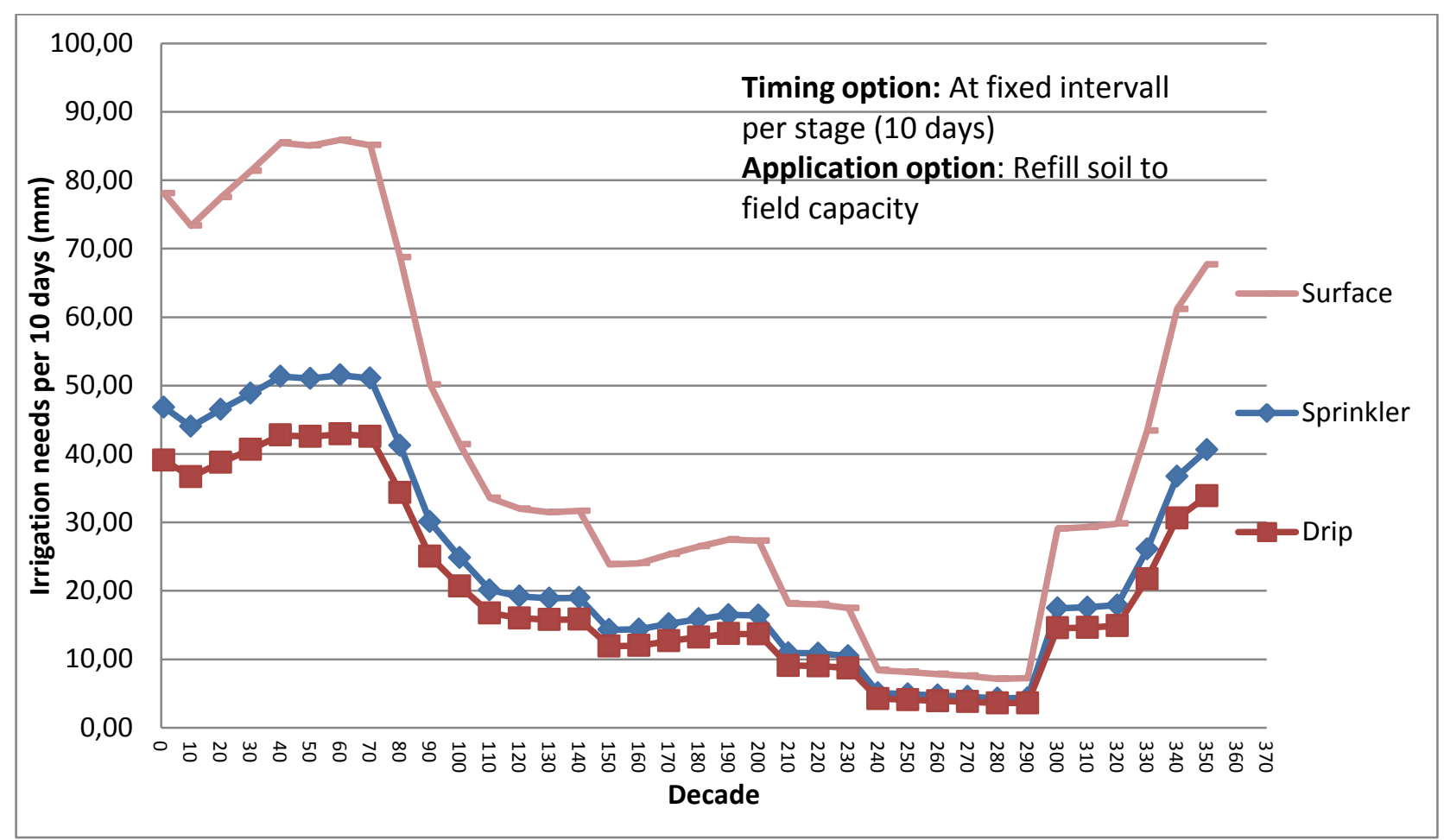

\subsection{Wind and solar pumping sizing}

The results of the simulations with PVSYST5 are shown in Table 7. As well as the suggested pump and array of solar panels, the system efficiency rating and the $\%$ of unfulfilled water demand are also shown. 
Table 7. Summary of parameters suggested by PVSYST5 for sizing solar pumping systems in the six scenarios comprising solar pumping

\begin{tabular}{|l|c|c|c|c|c|}
\hline & $\begin{array}{c}\text { Suggested pump } \\
\text { power (W) }\end{array}$ & $\begin{array}{c}\text { Suggested PV } \\
\text { power (Wp) }\end{array}$ & Pump selected & Array selected & $\begin{array}{c}\text { Unfulfilled } \\
\text { water } \\
\text { demand } \\
\text { (\%) }\end{array}$ \\
\hline CP1, Surface Irrig. & 1068 & 1349 & $\begin{array}{c}\text { Lorentz PS } \\
1200 \text { C-SJ5-8 }\end{array}$ & $\begin{array}{c}\text { 6 Modules Yingli } \\
240 \text { Wp 27V }\end{array}$ & 38.2 \\
\hline CP1, Sprinkler Irrig. & 623 & 787 & $\begin{array}{c}\text { Lorentz PS } \\
1200 \text { C-SJ5-8 }\end{array}$ & $\begin{array}{c}\text { 4 Modules Yingli } \\
210 \text { Wp 25V }\end{array}$ & 16.9 \\
\hline CP1, Drip Irrig. & 525 & 663 & $\begin{array}{c}\text { Lorentz PS } \\
1200 \text { C-SJ5-8 }\end{array}$ & $\begin{array}{c}4 \text { Modules Yingli } \\
170 \text { Wp 19V }\end{array}$ & 18.8 \\
\hline CP2, Surface Irrig. & 1061 & 1340 & $\begin{array}{c}\text { Lorentz PS } \\
1200 \text { C-SJ5-8 }\end{array}$ & $\begin{array}{c}\text { 6 Modules Yingli } \\
210 \text { Wp 25V }\end{array}$ & 24.8 \\
\hline CP2, Sprinkler Irrig. & 628 & 794 & $\begin{array}{c}\text { Lorentz PS } \\
1200 \text { C-SJ5-8 }\end{array}$ & $\begin{array}{c}3 \text { Modules Yingli } \\
265 \text { Wp 30V }\end{array}$ & 13.6 \\
\hline CP2, Drip Irrig. & 570 & 720 & $\begin{array}{c}\text { Lorentz PS } \\
1200 \text { C-SJ5-8 }\end{array}$ & $\begin{array}{c}\text { 4 Modules Yingli } \\
180 \text { Wp 19V }\end{array}$ & 9.1 \\
\hline
\end{tabular}

The pumping systems as suggested by PVSYST are similar for scenarios comprising the same irrigation technology. This means that the selection of the crop pattern does not affect the sizing of the pumping system. In the common crop pattern most of the water is needed in the first semester of the year due to the low precipitation rates in contrast with the second semester in which the common crops usually do not need irrigation water for growing. This demand is not the same for the cash crop pattern. In this case the irrigation water needs are also significant during the second part of the year, and in December especially there is an important difference between the two crop patterns. This is because it is assumed that by December the farmers have normally harvested the common crops from the second semester and will not start the next crop planting period until January. However, since fruit cash crops are perennial crops they create water demand throughout the whole year, especially in December as it is a month with typically low precipitation rates.

In the case of the windmill sizing the month with the highest reference area was September in scenarios applying the common crop pattern and November for those applying the cash crop pattern. Although the highest volume-head products needed are between January and March, these months are also characterised by high wind velocities, resulting in the reference area during this month being lower than the reference area in September and November, which is characterised by low wind velocities $(3 \mathrm{~m} / \mathrm{s}$ in September and $3.5 \mathrm{~m} / \mathrm{s}$ in November). Scenarios using surface irrigation require the highest amount of pumped water and it is only possible to meet this demand for water per hectare by using the largest windmill suggested by Jober (Ref 40120). For scenarios comprising sprinkler and 
drip irrigation technology, the demand for water can be met by the medium windmill reference 3590 (Table 8).

Table 8. Volume head product required in the windmill design month and its corresponding windmill reference suggested by manufacturer "Jober"

\begin{tabular}{|l|c|c|c|c|c|c|}
\hline & CP1 & CP1 & CP1 & CP2 & CP2 & CP2 \\
\hline $\begin{array}{l}\text { Volume-head } \\
\text { product September } \\
(\mathrm{m} 4)\end{array}$ & $\begin{array}{c}417 \\
\text { Jober 40120 }\end{array}$ & $\begin{array}{c}250 \\
\text { Jober 3590 }\end{array}$ & $\begin{array}{c}209 \\
\text { Jober 3590 }\end{array}$ & - & - & - \\
\hline $\begin{array}{l}\text { Volume-head } \\
\text { product November } \\
(\mathrm{m} 4)\end{array}$ & - & - & - & $\begin{array}{c}687 \\
\text { Jober 40120 }\end{array}$ & $\begin{array}{c}412 \\
\text { Jober 3590 }\end{array}$ & $\begin{array}{c}343 \\
\text { Jober 3590 }\end{array}$ \\
\hline
\end{tabular}

\subsection{Supply of pumped water}

The results of the monthly water supply for each technology are illustrated in terms of unfulfilled water demand in respect to the water demand for the PV and wind pumping systems in Fig 3 and Fig 4. These results show that particularly with the PV pumping system the volume of missing water is high during the first months of the year. This is because PVSYST suggests a system size that can better respond to the average water demand of each month. In the case of the wind pumping system the volume of missed water is lower than in case of the solar pumping system and it is more obvious in the months of lower wind speeds (September and November).

Fig 3. Unfulfilled water demand in scenarios with the solar pumping system

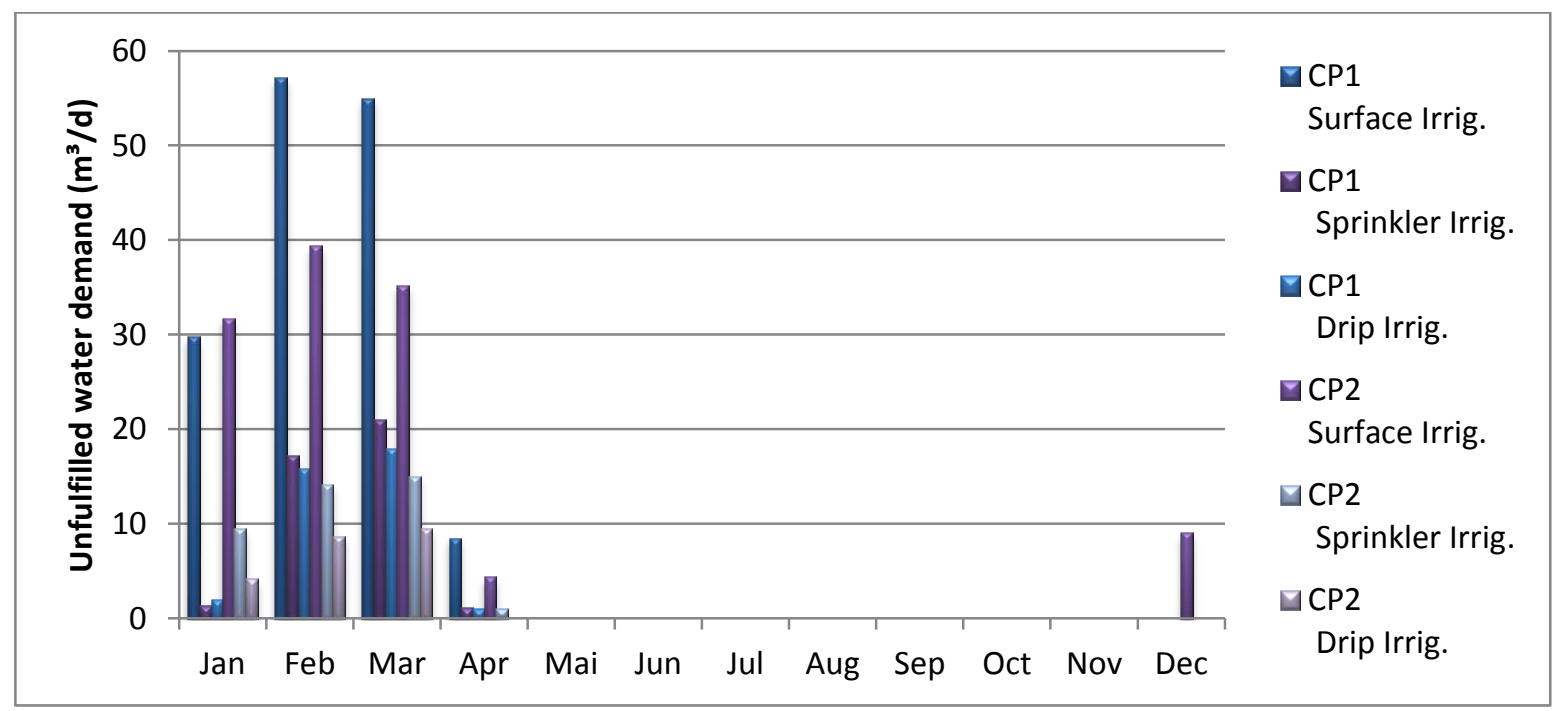


Fig 4. Unfulfilled water demand in scenarios with the wind pumping

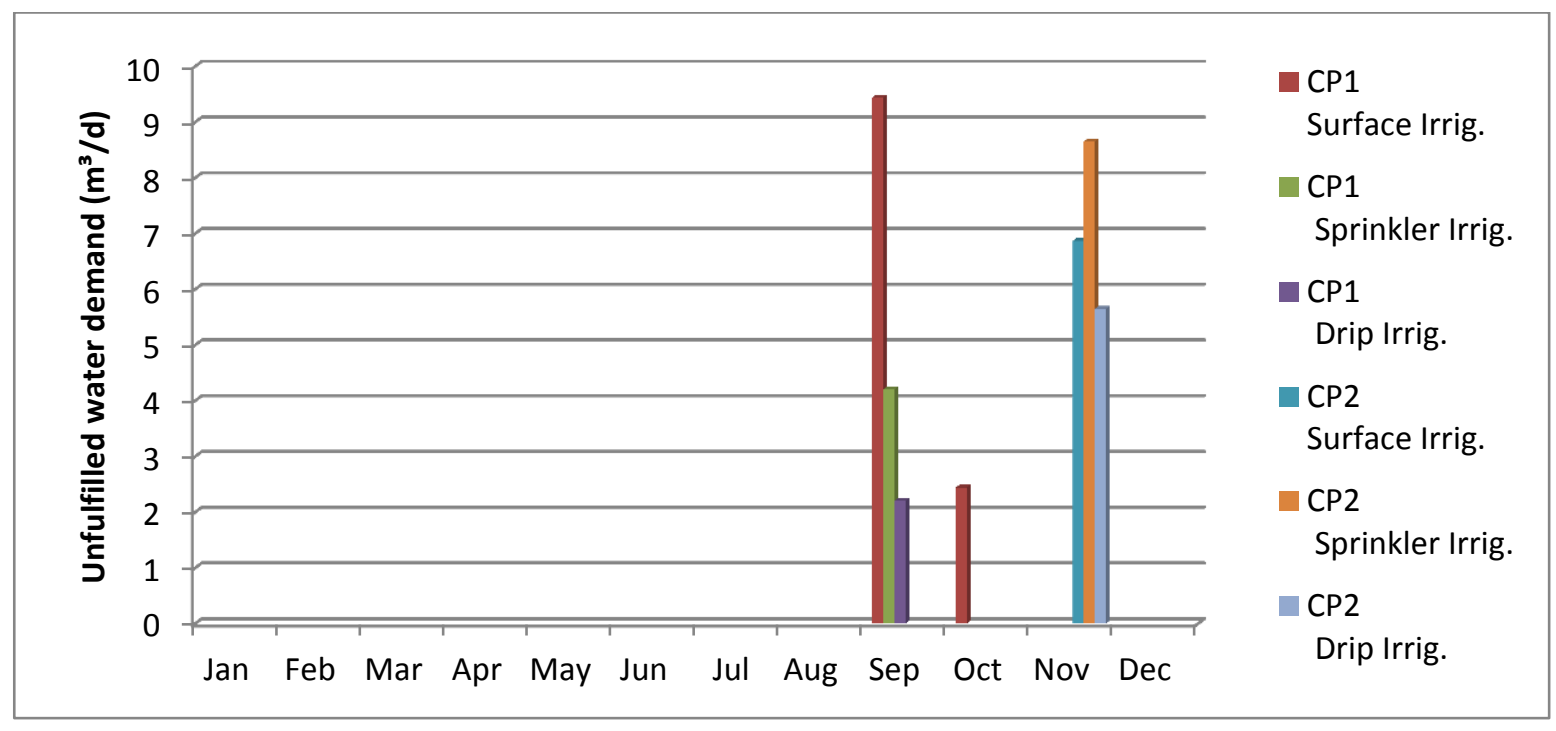

\subsection{Yield reductions}

The CROPWAT yield reduction results based on a normal rain year are shown in Table 9 for the common crop and fruit cash crop patterns. The dry season (December - April) shows a significant reduction in yield when no irrigation is provided. In some cases the yield reduction is $100 \%$ (i.e. for corn and beans in first semester), which means that theoretically it would not be possible to cultivate those crops in the period studied in a rain-fed scenario.

Table 9. Yield reduction simulation by different timing options

\begin{tabular}{|c|c|c|c|c|c|}
\hline \multicolumn{6}{|c|}{ Common Crop Pattern } \\
\hline \multirow[b]{2}{*}{ Crop } & \multirow{2}{*}{$\begin{array}{l}\text { Plant. } \\
\text { Date }\end{array}$} & \multirow{2}{*}{$\begin{array}{c}\text { Harvest } \\
\text { Date }\end{array}$} & \multicolumn{3}{|c|}{ Yield Reduction (\%) } \\
\hline & & & $\begin{array}{l}\text { At critical } \\
\text { depletion }\end{array}$ & $\begin{array}{l}\text { At fixed } \\
\text { intervals }\end{array}$ & $\begin{array}{l}\text { Without } \\
\text { Irrigation }\end{array}$ \\
\hline Sorghum & 01. Jan & 05.May & 0,1 & 8,5 & 78,1 \\
\hline Sorghum & 01. Jul & 02. Nov & 0,2 & 0,4 & 6,8 \\
\hline Corn & 01. Jan & 05.May & 0,2 & 10 & 100 \\
\hline Corn & 01.Jul & 02. Nov & 0,3 & 0,7 & 0,9 \\
\hline Manioc & 01. Apr & 27. Oct & 0,1 & 0,4 & 1,1 \\
\hline Millet & 01. Jan & 20. May & 0,2 & 3,3 & 94,8 \\
\hline Millet & 01. Jul & 17. Nov & 0,3 & 0,8 & 1 \\
\hline Beans & 01. Jan & 31. Mar & 0,3 & 24,7 & 100 \\
\hline Beans & 01. Jul & 28. Sep & 0,3 & 0,6 & 1,3 \\
\hline Watermelon & 01. Jan & 20. Apr & 0,2 & 5,8 & 96 \\
\hline Watermelon & 01. Jul & $180 \mathrm{ct}$ & 0,3 & 0,6 & 0,6 \\
\hline
\end{tabular}

\begin{tabular}{|l|c|c|c|}
\hline \multicolumn{4}{|c|}{ Fruit Cash Crop Pattern } \\
\hline \multirow{2}{*}{ Crop } & \multicolumn{3}{|c|}{ Yield Reduction(\%) } \\
\cline { 2 - 4 } & $\begin{array}{l}\text { At critical } \\
\text { depletion }\end{array}$ & $\begin{array}{c}\text { At fixed } \\
\text { intervals }\end{array}$ & $\begin{array}{l}\text { Without } \\
\text { irrigation }\end{array}$ \\
\hline Mango & 0,1 & 2,5 & 22,7 \\
\hline Avocado & 0 & 2,2 & 25,3 \\
\hline Lemon & 0,1 & 3,7 & 35,8 \\
\hline Gusnábans & 0,1 & 4,5 & 30,2 \\
\hline
\end{tabular}

These yield reductions are the basis for calculating the monetary value of each irrigation scenario. The revenues are the same for wind and diesel pumping in all irrigation methods (surface, sprinkler and drip irrigation). This is because the yield reduction of wind and diesel pumping under water supply 
conditions shows minimal differences to the yield reduction under water demand conditions. Solar pumping revenues differ by different irrigation methods: higher revenues are obtained by the sprinkler and drip irrigation systems than by the surface irrigation system. This suggests that a solar pumping system that is undersized for the month of highest water demand can produce higher crop revenues if a water efficient irrigation method such as sprinkler or drip irrigation is implemented.

\subsection{Economic analysis}

Results of the economic analysis for the three pumping systems are illustrated in Fig 5. The total technology costs were divided by the total yearly system supplied water. Windmills are found to be more cost effective than solar and diesel pumps in all combinations of crop patterns and irrigation systems. Solar pumps are more cost effective than diesel pumps when used for the fruit cash crop pattern. Diesel pumps are only more cost effective than solar pumps when the common crop pattern and surface irrigation method are applied. However, the pumping costs of diesel and solar based systems are very similar when the common crop pattern is combined with any other irrigation method (sprinkler or drip irrigation). These confirm the results of other studies, which suggest that solar pumping systems do not have economies of scale since in a surface irrigation scenario a higher amount of pumped water is needed [22]. The results of the present analysis confirm that solar pumping can have lower unit irrigation costs than diesel pumping when the irrigation requirements are better distributed throughout the year, which is the case in the scenarios for the cash crop pattern. It is important to point out that in scenarios applying diesel pumping the cost of water storage is not taken into account, since it was assumed that water was pumped and distributed when needed. Had the diesel pumping storage tank cost been considered, the diesel unit water cost would have been uncompetitive in comparison with solar pumping in all irrigation scenarios (as shown in Table 10).

Fig 5. Irrigation unit cost for each technology and crop scenario

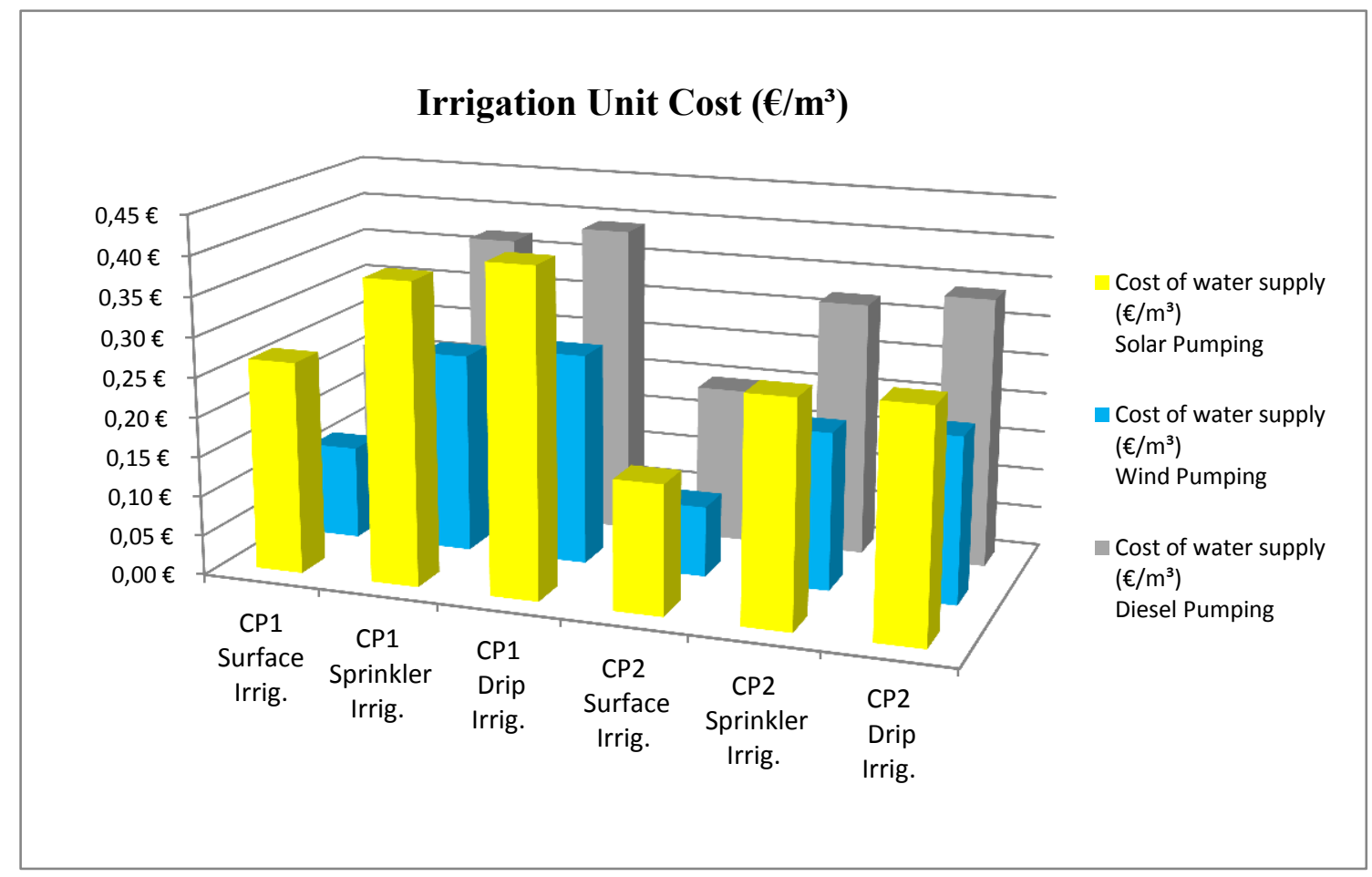


Table 10. Unit irrigation costs for solar, wind and diesel pumping

\begin{tabular}{|l|c|c|c|c|c|c|}
\hline & $\begin{array}{c}\text { CP1 } \\
\text { Surface } \\
\text { Irrig. }\end{array}$ & $\begin{array}{c}\text { CP1 } \\
\text { Sprinkler } \\
\text { Irrig. }\end{array}$ & $\begin{array}{c}\text { CP1 } \\
\text { Drip Irrig. }\end{array}$ & $\begin{array}{c}\text { CP2 } \\
\text { Surface } \\
\text { Irrig. }\end{array}$ & $\begin{array}{c}\text { CP2 } \\
\text { Sprinkler } \\
\text { Irrig. }\end{array}$ & $\begin{array}{c}\text { CP2 } \\
\text { Drip Irrig. }\end{array}$ \\
\hline $\begin{array}{l}\text { Cost of water supply } \\
\left(€ / \mathrm{m}^{3}\right) \\
\text { Solar Pumping }\end{array}$ & 0.27 & 0.38 & 0.41 & 0.16 & 0.28 & 0.29 \\
\hline $\begin{array}{l}\text { Cost of water supply } \\
\left(€ / \mathrm{m}^{3}\right) \\
\text { Wind Pumping }\end{array}$ & 0.12 & 0.25 & 0.27 & 0.09 & 0.20 & 0.21 \\
\hline $\begin{array}{l}\text { Cost of water supply } \\
\left(€ / \mathrm{m}^{3}\right) \\
\text { Diesel Pumping }\end{array}$ & 0.21 & 0.37 & 0.39 & 0.20 & 0.32 & 0.34 \\
\hline $\begin{array}{l}\text { Cost of water supply } \\
\left(€ / \mathrm{m}^{3}\right)\end{array}$ & 0.27 & 0.43 & 0.45 & 0.24 & 0.36 & 0.38 \\
$\begin{array}{l}\text { Diesel Pumping } \\
\text { with storage tank }\end{array}$ & & & & & & \\
\hline
\end{tabular}

\subsection{Cost-benefit analysis}

Cash flows were calculated for all 18 scenarios. The results are shown in Table 11 for scenarios using the common crop pattern and in Table 12 for those using the fruit cash crop pattern. Additionally, the revenues obtained for scenarios under rain-fed conditions were also calculated in present values after 20 years.

Common crop pattern: All scenarios comprising the common crop pattern are non-profitable over the whole period of analysis (20 years) when applying solar or diesel pumping. Only the windmill would result in some dividends; however, the initial payback period would be 14 years. In that case the highest dividends are obtained by applying surface irrigation, followed by drip and sprinkler irrigation. In general these results confirm the economic unfeasibility of irrigation of any type if it is only applied for subsistence farming.

Fruit cash crop pattern: All scenarios using the fruit cash crop pattern generate positive dividends after 20 years. The highest dividends were obtained from the wind pumping system and the lowest dividends were obtained from the diesel pumping system. The lowest payback period was obtained by the windmill after 7 years and this could even be reduced to 5 years if the surplus water was used to irrigate larger areas. Solar pumping is more profitable for all three irrigation types than diesel pumping.

Reference scenarios (rain-fed): The present values revenue obtained in rain-fed scenarios after 20 years were $€ 2224$ for the common crop pattern and $€ 17380$ for the fruit cash crop pattern. This means that in case of the common crop pattern, the dividends are actually higher without irrigation. This confirms again that investing in irrigation for subsistence farming is not profitable.

The dividends obtained from the fruit cash crop pattern without irrigation were in the range of between $€ 5200$ and $€ 11200$ lower than the dividends obtained with irrigation. This translates into additional incomes of around $€ 50$ per month after the sixth or seventh year, if the investment is made in solar or diesel based pumping. In cases where the farmer decides to power the irrigation by wind turbine, the dividend could be twice as much as the solar pumping dividends if the farmer decides to irrigate larger areas (for example 2 or 3 hectares). 
Table 11. Cash flow results for scenarios using the 'common crop' pattern (CP1) after 20 years

\begin{tabular}{|c|c|c|c|c|c|c|c|c|c|}
\hline & \multicolumn{3}{|c|}{ SOLAR PUMPING } & \multicolumn{3}{|c|}{ WIND PUMPING } & \multicolumn{3}{|c|}{ DIESEL PUMPING } \\
\hline & $\begin{array}{c}\text { CP1 } \\
\text { Surface } \\
\text { Irr. }\end{array}$ & $\begin{array}{c}\text { CP1 } \\
\text { Sprinkler } \\
\text { Irr. }\end{array}$ & $\begin{array}{c}\text { CP1 } \\
\text { Drip Irr. }\end{array}$ & $\begin{array}{c}\text { CP1 } \\
\text { Surface } \\
\text { Irr. }\end{array}$ & $\begin{array}{c}\text { CP1 } \\
\text { Sprinkler } \\
\text { Irr. }\end{array}$ & $\begin{array}{c}\text { CP1 } \\
\text { Drip Irr. }\end{array}$ & $\begin{array}{c}\text { CP1 } \\
\text { Surface } \\
\text { Irr. }\end{array}$ & $\begin{array}{c}\text { CP1 } \\
\text { Sprinkler } \\
\text { Irr. }\end{array}$ & $\begin{array}{c}\text { CP1 } \\
\text { Drip Irr. }\end{array}$ \\
\hline Total Costs $(€)$ & $(€ 36,764)$ & $(€ 41,156)$ & $(€ 35,691)$ & $(€ 26,937)$ & $(€ 33,198)$ & $(€ 29,085)$ & $(€ 58,234)$ & $(€ 49,385)$ & $(€ 49,756)$ \\
\hline Total Revenues $(€)$ & $€ 29,456$ & $€ 34,150$ & $€ 33,748$ & $€ 37,809$ & $€ 37,823$ & $€ 37,832$ & $€ 37,845$ & $€ 37,845$ & $€ 37,845$ \\
\hline PV Costs $(€)$ & $€ 5,465$ & $€ 6,118$ & $€ 5,305$ & $€ 4,004$ & $€ 4,935$ & $€ 4,323$ & $€ 8,656$ & $€ 7,341$ & $€ 7,396$ \\
\hline PV Revenues $(€)$ & $€ 4,378$ & $€ 5,076$ & $€ 5,016$ & $€ 5,620$ & $€ 5,622$ & $€ 5,623$ & $€ 5,625$ & $€ 5,625$ & $€ 5,625$ \\
\hline B/C Ratio & 0.80 & 0.83 & 0.95 & 1.40 & 1.14 & 1.30 & 0.65 & 0.77 & 0.76 \\
\hline Total Dividend in 20 y $(€)$ & $(€ 1,086)$ & $(€ 1,041)$ & $(€ 289)$ & $€ 1,616$ & $€ 688$ & $€ 1,300$ & $(€ 3,031)$ & $(€ 1,715)$ & $(€ 1,771)$ \\
\hline
\end{tabular}

Table 12. Cash flow results for scenarios using the 'cash crop' pattern (CP2) after 20 years

\begin{tabular}{|l|r|r|r|r|r|r|r|r|r|}
\hline & \multicolumn{3}{|c|}{ SOLAR PUMPING } & \multicolumn{3}{c|}{ WIND PUMPING } & \multicolumn{3}{c|}{ DIESEL PUMPING } \\
\hline & $\begin{array}{c}\text { CP 2 } \\
\text { Surface } \\
\text { Irr. }\end{array}$ & $\begin{array}{c}\text { CP2 } \\
\text { Sprinkler } \\
\text { Irr. }\end{array}$ & $\begin{array}{c}\text { CP2 } \\
\text { Drip Irr. }\end{array}$ & $\begin{array}{c}\text { CP2 } \\
\text { Surface } \\
\text { Irr. }\end{array}$ & $\begin{array}{c}\text { CP 2 } \\
\text { Sprinkler } \\
\text { Irr. }\end{array}$ & $\begin{array}{c}\text { CP2 } \\
\text { Drip Irr. }\end{array}$ & $\begin{array}{c}\text { CP2 } \\
\text { Surface } \\
\text { Irr. }\end{array}$ & $\begin{array}{c}\text { CP2 } \\
\text { Sprinkler } \\
\text { Irr. }\end{array}$ & $\begin{array}{c}\text { CP2 } \\
\text { Drip Irr. }\end{array}$ \\
\hline Total Costs $(€)$ & $(€ 34,846)$ & $(€ 39,700)$ & $(€ 35,376)$ & $(€ 26,004)$ & $(€ 32,266)$ & $(€ 28,618)$ & $(€ 67,499)$ & $(€ 61,475)$ & $(€ 57,424)$ \\
\hline Total Revenues $(€)$ & $€ 206,598$ & $€ 212,367$ & $€ 212,367$ & $€ 218,560$ & $€ 217,869$ & $€ 218,529$ & $€ 219,534$ & $€ 219,534$ & $€ 219,534$ \\
\hline PV Costs $(€)$ & $€ 5,180$ & $€ 5,901$ & $€ 5,258$ & $€ 3,865$ & $€ 4,796$ & $€ 4,254$ & $€ 10,033$ & $€ 9,138$ & $€ 8,536$ \\
\hline PV Revenues $(€)$ & $€ 30,709$ & $€ 31,567$ & $€ 31,567$ & $€ 32,488$ & $€ 32,385$ & $€ 32,483$ & $€ 32,632$ & $€ 32,632$ & $€ 32,632$ \\
\hline Payback year & 8 & 8 & 8 & 7 & 8 & 7 & 8 & 8 & 8 \\
\hline B/C Ratio & 5.93 & 5.35 & 6.00 & 8.40 & 6.75 & 7.64 & 3.25 & 3.57 & 3.82 \\
\hline Total Dividend in $20 \mathrm{y}(€)$ & $€ 25,530$ & $€ 25,666$ & $€ 26,309$ & $€ 28,622$ & $€ 27,589$ & $€ 28,229$ & $€ 22,599$ & $€ 23,494$ & $€ 24,097$ \\
\hline
\end{tabular}

\section{Discussion}

This study draws conclusions about the technical and economic feasibility of renewable energy pumping systems. These statements followed assumptions that were carefully chosen according to the conditions in the case study area and region. These statements are valid as a first approach for further research on this topic. This section will, therefore, discuss all the variables that should be taken into account for future analysis.

\subsection{Crop pattern and crop irrigation requirements}

The selection of the crop pattern for the simulation of the irrigation requirements in CROPWAT is based on statistical data and observations done in the field. The common crop pattern comprises two harvest seasons per year. Each harvest season has a total crop length of 4 months starting in January and July respectively. Two months in each semester are not planted, which means that the irrigation requirements in those months were zero. This was different in the fruit cash crop pattern, which has a permanent irrigation requirement during the whole year. Therefore it is relevant at the beginning of the project to propose a crop pattern that is well distributed throughout the year in order to improve the productivity of the farm. 


\subsection{Wind pumping system for more than 1 hectare}

The windmill water supply in all cases exceeds the crop water demand of the 1 ha cultivated area for several months of the year. It is important to remember that this characteristic emerges from the fact that the wind pumping systems are sized based on the months of highest reference area, i.e. September for the common crop scenario and November for the fruit cash crop scenario. During those months the water supplied by the selected wind pumping systems does not even meet the demand for one hectare. As the cost-benefit analysis of all scenarios comprising wind pumping demonstrated the technology to be economically feasible, even without any use being considered for the surplus water, there seem to be two options for further optimisation (and further research) of irrigation schemes based on wind: a) considering the use of surplus water for additional areas and b) considering the use of the next smallest size of commercially available windmills.

\subsection{Solar pumping system}

The monthly volume supplied water from the solar pumping system sized with PVSYST does not result in high water surpluses as in the case of the windmills. This is because PVSYST suggests a system size that achieves a trade-off between system efficiency and a lack of water in the months of higher water demand. Between January and March the missing water is in the range of between $20 \%$ and $30 \%$ of the water demand. This means that the unit irrigation cost calculated for 1 ha (Fig 5) nearly corresponds to the cost of the water pumped if all the supply water was to be used for irrigation purposes. During the months of low water demand (i.e. the second part of the year) the solar pumping system does not take advantage of its whole potential. This potential surplus water is not considered by PVSYST because the software assumes the pump will shut off when the water demand is met.

\subsection{Diesel pumping system}

In relation to the unit irrigation costs from the diesel pumping system it is necessary to emphasise the significant weight of operational (fuel) costs in the calculations. The diesel fuel costs are assumed to increase proportionally with annual inflation rates. It was not possible to anticipate diesel fuel price escalation in Colombia over the next 20 years; although global diesel price projections do exist, these were not considered in this study.

\subsection{Irrigation method}

No notable differences are found in the cash flow results for surface, sprinkler and drip irrigation systems, excepting for in the case of surface irrigation using solar pumping. In this case higher pumping costs are caused by a larger PV system size. If a windmill is used the irrigation method would have a greater impact in the decision because the farmer could use the water saved by a more efficient irrigation system (e.g. sprinkler or drip) for irrigating an extra area.

\subsection{Storage tank}

The storage tank capacity was assumed to be 0.5 days in the month of highest water demand. Although this volume is the lowest recommended by many authors, this capacity was found to be appropriate for 
the system demand during the year. Between April and December the storage tank can meet at least one day of the water demand (or even greater volumes during some months). Only between January and March the minimal 0.5 days storage security would be valid. Based on this premise and considering the high construction costs of a concrete storage tank for larger volumes, the 0.5 days storage assumption was demonstrated to be appropriate.

\subsection{Revenues with irrigation and under rain-fed conditions}

Revenues with irrigation were very similar in both scenarios since the change of yield reduction under supply conditions was minimal when compared with the yield reductions under irrigation conditions every 10 days. The only important variation in revenues was found in the solar pumping system since here the lower water supply had a greater impact on the yield reduction of the first semester crops than the wind and diesel pumping systems. Revenues without irrigation confirmed the fact that irrigation is only feasible in a cash crop scenario.

\section{Conclusions}

This study analysed the technical and economic feasibility of solar and wind pumping systems for irrigation on small farms in the Caribbean region of Colombia. Technically both renewable based pumping systems can be sized and installed to meet the irrigation water requirements of the two proposed cropping patterns. The results of the study indicate that windmills are feasible technical and economic alternatives for the irrigation of small farms in the region of study. The use of solar driven irrigation systems also offers some interesting potential. Moreover, the results clearly indicate that the provision of water for irrigation alone is not enough to improve the economic performance of small farms. Reorienting the crop pattern of the farm towards commercial products is also needed. The results also show that the combination of both strategies (irrigation and reorientation of cropping) achieves the highest benefits.

\section{Acknowledgments}

This paper is derived from a master thesis submitted at ITT CUAS. Authors thank to the WISIONS team at the Wuppertal Institute for their collaboration while developing the master thesis.

\section{Conflicts of Interest}

The authors declare no conflicts of interest.

\section{References}

1. Meier, T. Policy Recommendations to Improve the Sustainability of Rural Water Supply Systems. In Proceeding of the International Off-grid Renewable Energy Conference. Accra, Ghana, November 2012. Available online: http://iorec.org/pdf/1_Session\%205.pdf (accessed on 8 June 2013).

2. WWAP, 2012. World Water Assessment Programme, The United Nations World Water Development Report 4: Managing Water under Uncertainty and Risk. Paris, UNESCO.

3. IOREC. International Off-Grid Renewable Energy Conference: Key Findings and Recommendations. Accra, Ghana, November 2012. Available online: 
http://www.irena.org/DocumentDownloads/Publications/IOREC_Key\%20Findings\%20and \%20Recommendations.pdf (Accessed on 9 June 2013).

4. De Oliveira, A.S.; Trezza, R.; Holzapfel E.A.; Lorite, I.; Paz, V.P.S. Irrigation Water Management in Latin America. Chilean J. Agric 2009,69, ISSN 0718-5839.

5. Hidraco SAS. 2012. Distritos de Riego en Colombia: Panorama. Available online: http://hidracol.blogspot.de/2012_02_01_archive.html (accessed on 5 May 2014).

6. IDEAM. 2010. Estudio Nacional de Agua. Available online: https://documentacion.ideam.gov.co/openbiblio/Bvirtual/021888/021888.html (accessed on 08 May 2014).

7. FAO Aquastat Database. 1988-2002. Available online: http://www.fao.org/nr/water/aquastat/data/query/ (accessed on 08 May 2014).

8. Piojó's Mayor office. 2010. Esquema de Ordenamiento Territorial 2010-2022. Available online: http://piojo-atlantico.gov.co/apc-aa-files/65363635306237373434336634623662/eotpiojo-diagnostico1_1.pdf (accessed on 5 May 2014).

9. Agronet. Evaluaciones Agropecuarias Municipales 2007-2012 (National Agricultural Information and Communication Network of Colombia). Available online: http://www.agronet.gov.co (accessed on 9 December 2013).

10. ENA, 2012. Estadísticas agrícolas y pecuarias. Available online: https://www.dane.gov.co/index.php/agropecuario-alias/estadisticas-agricolas-y-pecuarias-ena [accessed on 10 May 2013]

11. Allen, R.; Pereira, L.; Raes, D.; Smith, M. 1990. Crop Evapotranspiration (guidelines for computing crop water requirements), FAO Irrigation and Drainage Paper No. 56.

12. IDEAM. 2013. Precipitation data (1993-2013) of the Hibácharos meteorological station in the Municipality of Piojó.

13. Polo, D. 2013. Visit to Palmar de Varela, Atlantic Department, Colombia: Conversation about windmills in the region. (Personal communication, June 2013)

14. Kay, M.; Hatcho, N. 1992. Small scale pumped irrigation: energy and cost, FAO Land and Water Development Division.

15. Pinilla, A.E. 1985. Wind Powered Pumping System for Colombia. Ph.D. Thesis, Reading, England.

16. Van Meel, J.; Smulders, P. 1989. Wind Pumping a Handbook. World Bank-Technical Paper Nr.101

17. Barnes, 2014. Pumps performance curves. Available online: http://www.barnes.com.co (accessed on 25 May 2014)

18. Kelley, L.C.; Gilbertson, E.; Sheikh, A.; Eppinger, S.D.; Dubowsky, S. On the feasibility of solar-powered irrigation, Renewable and Sustainable Energy Reviews 2010, 14, 2669-2682.

19. Riggs, J.; Bedworth, D.; Randhawa, S. Engineering Economics, 4th ed.; McGraw-Hill: New York, NY, USA, 1996

20. Short, W.; Packey, D.J.; Holt, T. 1995. A Manual for the Economic Evaluation of Energy Efficiency and Renewable Energy Technologies. National Renewable Energy Laboratory, Golden-Colorado U.S.

21. SIPSA, 2014. Sistema de información de precios. Available online: https://www.dane.gov.co/index.php/agropecuario/sistema-de-informacion-de-precios-delsector-agropecuario-sipsa (accessed on 23 June 2014).

22. Ramos, J.S.; Ramos, H. M. Solar powered pumps to supply water for rural or isolated zones: A case study, Energy for Sustainable Development 2009, 13, 151-158

(C) 2014 by the authors; licensee MDPI, Basel, Switzerland. This article is an open access article distributed under the terms and conditions of the Creative Commons Attribution license. 